\title{
Constitutional Development Stages in Kyrgyzstan
}

\author{
Aida Duishonbaeva1, Aktilek Atantaev², Toktobubu Akparali kyzy33, Aruuke Sultanova4, \\ Tazhibai Aitbaev', Kim Jung Yong4, Aizhamal Zhusupova5, Akmaral Matkasymova6, \\ Zhypargul Abdullaeva ${ }^{*}$ (C)
}

\author{
${ }^{1}$ Department of General History and Teaching Methods, Osh State University, Osh, Kyrgyzstan \\ ${ }^{2}$ Department of Civil Law and Procedure, Osh State University, Osh, Kyrgyzstan \\ ${ }^{3}$ Secondary School named after A. Navoyi, Osh, Kyrgyzstan \\ ${ }^{4}$ International High School of Educational Programs, Bishkek, Kyrgyzstan \\ ${ }^{5}$ Secondary School named after A. Sayt, Osh, Kyrgyzstan \\ ${ }^{6}$ Secondary School named after K. Altybaev, Osh, Kyrgyzstan \\ ${ }^{7}$ Science and Research Department, Osh State University, Osh, Kyrgyzstan \\ Email: ^jypar.science@oshsu.kg
}

How to cite this paper: Duishonbaeva, A. Atantaev, A., Akparali kyzy, T., Sultanova, A., Aitbaev, T., Yong, K. J., Zhusupova, A., Matkasymova, A., \& Abdullaeva, Z. (2021). Constitutional Development Stages in Kyrgyzstan. Open Journal of Social Sciences, 9, 238-247.

https://doi.org/10.4236/jss.2021.910017

Received: September 17, 2021

Accepted: October 22, 2021

Published: October 25, 2021

Copyright (c) 2021 by author(s) and Scientific Research Publishing Inc. This work is licensed under the Creative Commons Attribution International License (CC BY 4.0).

http://creativecommons.org/licenses/by/4.0/

\begin{abstract}
This article examines constitutional development stages in Kyrgyzstan including Constitution and the constitutional system that appeared during the Soviet period. The Constitution of Kyrgyzstan went through the same stages in its development as the Kyrgyz government as a whole, both in the Soviet and in the sovereign, independent period in the history of Kyrgyzstan. The study of archival documents let us restore historical truth and the list of names of all members in the commissions for drafting the Constitutions in both the Soviet period and in sovereign independent Kyrgyzstan.
\end{abstract}

\section{Keywords}

Constitution, Constitutional Order, Government, Soviet Power, Sovereignty, Fundamental Law, Archival Documents, Historical Truth

\section{Introduction}

We suppose that it is one thing to have a government's Constitution, but it is another thing to reveal when, by whom and how these Constitutions were developed, prepared, formed, how various drafts of different Constitutions were written. Constitutions are usually issued in the form of a contract between the ruler and the ruled by a constitutionally formed national assembly, or through a general referendum, also constitutional documents played a role in rendering 
the royalty more accountable and responsive to domestic needs (Lavie, 2021: p. 1). The constitution remains evolutionary, responding piecemeal in pragmatic solutions developments through a series of specific problems (Young et al., 2019: p. 85); Constitutional Law Committee plays an important role in ensuring the conformity of legislation with the Constitution (Albi, 2019: p. 57). Referendums are determined as important instruments in the democratic innovation against the crisis (Kersting \& Grömping, 2021: p. 2).

This, in turn, allows the current and young generation to know who is responsible for the preparation of the Basic Laws of the country, at different periods of its development. We also suppose that not only young people but also many representatives of the older generation still do not know how many draft versions of the first Constitution in history were prepared from 1926 to 1929 years.

Undoubtedly, the Kyrgyz are one of the most ancient people not only in the Central Asian region (Alymkozhoev, 2015: p. 45) but in the whole world. Kyrgyz people have retained their ethnic name, originality, national characteristics and their own culture through millennia of complex historical and political processes (Tokpayeva, 2013: p. 211).

However, despite the fact, that the Kyrgyz people and the Kyrgyz government have a long history, until recently, the Kyrgyz did not have a Constitution in the classical representation (Sheripov, 2014). It is well known that our people have lived without any Constitution for centuries. They lived and created history, ruled their state thanks to the traditions, customs and imperative rules of their ancestors, who passed from generation to generation orally.

Gradually, a tradition of customs developed, which grew into rules and regulations in the form of "Adat", "Erezhe", in which all the normative legal acts were recorded (Kuldysheva et al., 2021: p. 323) and which were carried out by everyone unshakably and unquestioningly instead of the Constitution (Saitbekov, 2016: p. 244). Consequently, for the Kyrgyz people and government, the Constitution is considered as a classical concept that is relatively recent, alien historical and political culture. The constitution appeared in the Kyrgyz people's life with the appearance of the Russian people and Russian colonialization at the beginning of the twentieth century (Dononbaeva, 2016: p. 53). Even among the Russian people, the Constitution appeared at the beginning of the twentieth century. The constitution of Kyrgyzstan went through the same stages in its development as the Kyrgyz statehood as a whole, both of the Soviet and the sovereign and independent period of the history of Kyrgyzstan.

We suppose that it is one thing to have a government's Constitution and another thing to reveal when by whom and how these Constitutions were developed. In preparation, formation of Constitution different drafts, the following stages in the constitutional development can be distinguished:

1) The Kyrgyz government constitution during the transition from the patriarchal feudal system to socialism, bypassing capitalism. In other words, the constitution of the Kyrgyz government developed in the form of autonomy 
(1929);

2) The Constitution of the Kyrgyz government during the consolidation and completion of the socialism construction. In other words, the Kyrgyz government Constitution developed in the form of a union republic (1937);

3) The Kyrgyz government constitution consolidated the construction of socialism development. In other words, the constitution that secured further development of the Kyrgyz government (1978);

4) Constitution of an independent Kyrgyz government (1993);

5) Constitution of the Kyrgyz Republic (2010).

\section{Research Methods and Materials}

This article is based on the literature analysis and historical-comparative methods describing the Kyrgyz government constitutional development stages in various periods, notions about the Kyrgyz Autonomous Soviet Socialist Republic Constitution development and referendum nationwide voting. The main issues discussed are the constitutional development stages in Kyrgyzstan including Constitution and the constitutional system that appeared during the Soviet period. Research materials are based on the Kyrgyz Republic Constitution articles covering the 1929 to 2016 years.

The research process is shown in 8 stages including an initial stage in the constitutional development of Kyrgyzstan; the second stage beginning with the adoption of Kyrgyz ASSR's own Constitution in 1929; the third stage of constitutional development begins with the adoption of the so-called Stalinist Constitution of the USSR in 1936; the fourth stage beginning from the adoption of the Kyrgyz SSR Constitution in 1978; the fifth stage including constitutional reforming of the Akayev period or regime; sixth stage of constitutional reforms began after the March revolution, with the coming to power of $\mathrm{K}$. Bakiev; the seventh stage covering the period from 2010 to 2016; the eighth stage in the constitutional development from 2016 to recent days.

\section{Results and Discussions}

Based on the first Constitution established in 1993, a large-scale, revolutionary transformation of post-Soviet government and society began in Kyrgyzstan. However, our society failed to fully realize the great potential that was laid in the Constitution in 1993 (Kyrgyz Republic Ministry of Justice, 2021). To resolve political and constitutional-legal problems, primarily related to the President functions, and power of the Jogorku Kenesh (Asanbekova et al., 2021: p. 270) and the Government beginning from the second half of the 90s of the last century, the authorities have chosen a vicious method in amending the current Constitution version.

Following the government structure, setting goals and objectives, building national government at different periods in the Kyrgyz people development performed under Constitution of various government unions. 
According to this, as well as from a certain stage in the development of the government under various Constitutions, we undertook the main stages of the constitutional development in Kyrgyzstan (Toktogulov, 2016: p. 66) consistently, in a chronological and logical sequence following historical formation and development.

Before these, we have identified very important issues offering our own vision and highlighting the main stages in the constitutional development, starting from 1918 to 2016. At the same time, we are highlighting each specific stage in the constitutional development, proceeded from the specific case of the government development. Based on the above, we have identified the following stages in the Kyrgyz Republic Constitutional development:

1) The first stage is covering the years from 1918 to 1929, the initial stage when the constitutional development of Kyrgyzstan, on the path of revival began in the Soviets period, in the composition of other government associations. It is known that initially after the establishment of Soviet power, the Kyrgyz people acquired an autonomous statehood represented by the Turkestan ASSR (1918-1924). Accordingly, they lived under the Constitution of the Turkmen ASSR. Indeed, it was a politically very difficult time in the Central Asian autonomy.

Moreover, it was the autonomy of the peoples of the former Turkestan general-governor of tsarist Russia, which did not completely satisfy the political, socio-economic and even cultural interests of specific nations and peoples. Many questions of the aforementioned very important spheres in social and political life remained unresolved.

Formation of the newest Kyrgyz government determined by the Constitutions of the Turkestan ASSR as part of the RSFSR, as well as the RSFSR and the USSR. Thus, from 1918 to 1929, the Kyrgyz did not have their own Constitution.

2) The second stage covers 1929 to 1937 years. This stage begins with the adoption of Kyrgyz ASSR's own Constitution in 1929. This event became an important milestone in the history of the constitutional development of Kyrgyzstan, in fact, from this period the constitutional development of Kyrgyzstan begins. Consequently, the second stage was marked by the development with the Kyrgyz people representatives followed by a long discussion, introduction of amendments, changes and finally the adoption of own Constitution in the Kyrgyz Autonomous Soviet Socialist Republic in 1929.

It should be noted that the development of the Kyrgyz Autonomous Soviet Socialist Republic Constitution began even before the transformation of the Kyrgyz Autonomous Region into the Kyrgyz Autonomous Soviet Socialist Republic. The development, changes, additions to Constitution began in 1926 when a special commission was formed to develop the Constitution of the Kyrgyz ASSR.

Looking ahead, we note that in general, over the years of the development of the first Constitution of Kyrgyzstan from 1926 to 1927. Four different drafts of the Basic Law of the Kyrgyz Republic were developed and proposed to the higher 
party and government bodies of ASSR. Unfortunately, not all of them suited the leadership of the RSFSR and the USSR, which included the Kyrgyz Republic. Consequently, for such reasons, the Constitution was not ready by 1927, and accordingly, the proposed version of the constitutional commission was not adopted.

3) The third stage covers periods from 1937 to 1978 . This stage of constitutional development begins with the adoption of the so-called Stalinist Constitution of the USSR in 1936, and the corresponding Constitution of the newly made Kyrgyz SSR in 1937 as part of the USSR. Note that this historical process was preceded by the transformation of the Kyrgyz ASSR into the Kyrgyz SSR.

The government apparatus of the Kyrgyz Autonomous Soviet Socialist Republic predominantly consisted of representatives of the indigenous population, office work, legal proceedings and education carried out in the Kyrgyz language, taking into account the interests of other nationalities living in the territory of Kyrgyzstan. The Kyrgyz ASSR did not have sovereignty but enjoyed broad rights of self-government. She, being an equal federal part of the RSFSR, had broad powers in all areas of social, political, national economic and cultural life. The need for a great similarity of the texts of the basic laws was justified by the commonality of political and economic systems, the unity of goals, authorities' structure and tasks. Moreover, it was the Constitution constructed in the socialist period.

4) The fourth stage covers 1978 to 1993 years. This stage begins with the adoption of the Kyrgyz SSR Constitution in 1978. The Constitution (Basic Law) of the Kyrgyz SSR, adopted on April 20, 1978, consisted of 10 sections, 19 chapters and 172 articles (Kyrgyz Republic Ministry of Justice, 1987). The Constitution established in 1978 despite its extreme ideology and fictitiousness in many respects, was of great importance, as it legislatively consolidated the qualitative changes that took place in the Kyrgyz people's national government development.

5) The fifth stage includes the 1993-2005 years; conditionally this stage can be called as constitutional reforming of the Akayev period or regime. This stage was marked by the development and adoption of the first Constitution, the Basic Law of sovereign and independent Kyrgyzstan in 1993. On October 27, 1990, the Supreme Council of the republic of the twelfth convocation adopted a resolution on education.

Over the next three years, the commission for drafting a new Constitution, the public and deputies have developed their versions of the country's main document. Developed and adopted on May 5, 1993, the Constitution of the Kyrgyz Republic is the most important stage in the formation of new Kyrgyz statehood, which has acquired a new legal framework as a sovereign, democratic, legal, secular, unitary, social government.

The most important and key points in the 1993 Constitution were the Kyrgyz Republic's independence principles concerning freedom, speech and democracy. This Constitution is the legal basis of statehood, social development, democratic 
foundations, economic and ideological principles of modern Kyrgyzstan.

It is known that at the fifth stage of constitutional development, the country received a logically consistent constitutional reform, due to the historical and political events in our country in March 2005. However, this was preceded by the constitutional reforms of the Akayev period, which began three years after the adoption of the first Constitution in the sovereign and independent Kyrgyz Republic. In a further stage of society development, changes in the political leadership, strengthening of personal power over the country, changes in constitutional norms were required, in the interests of determining forces or other political groups.

According to world practice, any constitutional reform is characterized as progressive, systematic and evolutionary progress. However, the constitutional reforms in Kyrgyzstan, in the Akayev period, pursued the interests of one person and his closest circle, in this case of President A. Akayev. To strengthen his position and increase his powers, to redistribute power, of course, A. Akaev went to constitutional reforms in his favour three and more times.

Consequently, such constitutional reforms took place starting from January 3 , 1996, according to the Decree of the President of the Kyrgyz Republic A. Akayev on the conduct of a referendum issue of delimiting powers between the branches of government power. It was carried out by a referendum on February 10, 1996, by the adoption of the Law "On Amendments and Additions to the Constitution of the Kyrgyz Republic".

The next constitutional reform carried out following the Decree of the Kyrgyz Republic President dated September 1, 1998 No. 270 "On the nationwide discussion of the draft Law of the Kyrgyz Republic" and "On amendments and additions to the Constitution of the Kyrgyz Republic" (Kyrgyz Republic Ministry of Justice, 2021), after that by Decree of the Kyrgyz Republic President "On the referendum (nationwide voting) in the Kyrgyz Republic on October 17, 1998" dated October 1, 1998. As a result of the referendum, the Law "On Amendments and Additions to the Constitution of the Kyrgyz Republic" was adopted. According to which several changes were introduced in the new edition of the 1998s Constitution.

On January 13, 2003, the Decree of the Kyrgyz Republic President was issued from the Decree of President No. 8 "On holding a referendum in the Kyrgyz Republic" in February 2003 (Kyrgyz Republic Ministry of Justice, 2003). At the referendum, the overwhelming majority of citizens spoke in favour of the adoption of the amendments to the Kyrgyz Republic Constitution proposed by law. Thus, the fifth stage, as it was conventionally called as a stage of constitutional reforms during Akaev regime; Constitution was forged four times, and in the end led to the usurpation of power by the family of Akaevs and their entourage. The result was the March people's revolution and the overthrow of the Akayev regime, its clan and associates.

The practice and course of historical and political events have shown that one cannot neglect the desires, aspirations and aspirations of the people, who 
brought this or that political figure to power. Neglect paved the way for the next stage of constitutional development and reform.

6) The sixth stage covering periods from 2005 to 2009. This stage of constitutional reforms began after the March revolution, with the coming to power of K. Bakiev. In a short time, over 5 years, the then President Bakiev managed to carry out two scandalous and noisy constitutional reforms. The sixth stage of the constitutional development of Kyrgyzstan is associated with the adoption of two laws.

This stage is characterized by the fact that the reforming is carried out against the background of post-revolutionary Kyrgyzstan and the change of political power after political events, the March 2005 revolution. It was the time of searches and post-revolutionary transformations in the republic.

Some innovations have appeared in the Constitution:

1) The parliament of the Kyrgyz Republic was supposed to consist of 90 deputies, at least 50 percent were to be elected according to the proportional system;

2) The President, on the proposal of the National Council for the Affairs of Justice of the Republic, presents to the Parliament candidates for election to the posts of judges of the Constitutional Court, the Supreme Court; gender equality was introduced in the public administration system;

3) The government recognized the right of a citizen to have dual citizenship;

4) Constitutional changes were introduced: the key role of the president was noted, the powers of the president were strengthened regarding the formation of the government, the determination of the structure of the government, the accountability of the government to the president was established;

5) The prime minister proposes to the president nominations for the posts of members of the government, except for members of the government in charge of defense and security;

6) The powers of the president are also supplemented by the right to appoint, in agreement with the prime minister, heads of local state administrations, as well as to dismiss them from office;

7) The president was empowered to suspend the regulatory legal acts of the government and other executive authorities.

7) The seventh stage covers the period from 2010 to 2016. More details about the essence and significance of the 2010 constitutional reform will be described in the corresponding section below. This stage of constitutional reform was also marked by political changes, a change of power and a change in the political course in the Kyrgyz Republic. This stage of the constitutional reform of Kyrgyzstan was marked by the adoption of the new Constitution of the Kyrgyz Republic, adopted by a referendum on June 27, 2010.

Note that Decree No. 1 of the Provisional Government of 2010 established that the Constitution adopted by a referendum on October 21, 2007, April 21, 2010, continues to operate in the Kyrgyz Republic until the adoption of the new edition. The government approved the person responsible for the preparation of 
the referendum on the Constitution of the Kyrgyz Republic in the person of the Deputy Chairman of the Provisional Government O. Tekebaev.

Consequently, the responsibility for this stage of the consultation reform agrees with the Provisional Government and specifically O. Tekebaev, who was considered as father of 2010 Kyrgyz Republic Constitution. It contains a large number of amendments, mainly concerning words and formulations in the government language. As it turned out later, gross errors and discrepancies with the Russian text were again not completely cleaned out. The full text of the draft, taking into account the amendments made to it, was not published by the Provisional Government until the referendum.

This document regulated the issues of holding a referendum in certain regions of the state of emergency, which was introduced in connection with the tragic June events. Thus, on June 27, 2010, at the height of the political crisis and interethnic conflict in the south of the country, under the responsibility of the Provisional Government, a new Constitution of the Kyrgyz Republic was adopted through a referendum.

During the referendum, despite the difficult political situation, $90 \%$ of the participants supported the new Constitution of the Kyrgyz Republic. It was this draft of the new Constitution, initiated by the interim government, which received the approval of $1,777,339$ citizens, or $90.55 \%$ of the votes cast, in a nationwide referendum.

According to the new Constitution, the supremacy of the power of the people is established, represented and ensured by the popularly elected Jogorku Kenesh and the president; the state power is divided into legislative, executive, judicial branches; the president is assigned the role of head of state and arbiter. The powers of the president have been drastically reduced.

The new Constitution establishes a fundamentally new form of government-the parliamentary republic, where the key role is assigned to the Jogorku Kenesh, and political diversity and a multi-party system are recognized. Unfortunately, this moratorium on introducing changes and amendments to the Constitution until 2020 could not provide for all the changes that took place in the country after the April revolution. And the prevailing socio-political situation led to the fact that by 2016 it became clear that there was an urgent need to make changes and additions to the Basic Law-the Constitution of the Kyrgyz Republic. Consequently, there is a new need for constitutional reform.

8) The eighth stage is from 2016 to the present day. This constitutional reform of the Kyrgyz Republic was carried out by a popular vote in a referendum "On Amendments to the Constitution of the Kyrgyz Republic" on December 11, 2016. For five years, we adhered to the constitutional norm of the previous edition, which prohibited the reform to reconcile the Constitution, introduced restrictions on amendments to the current Constitution until 2020.

However, many areas of public-political development of the country went against the Constitution of the country in 2010. The social and political situation 
in the country, the change in the state system and other reasons led to the fact that the current leadership of the country was forced to go for new constitutional reforms. So, on May 22, 2015, the draft Law of the Kyrgyz Republic "On Amendments to the Constitution of the Kyrgyz Republic" was submitted for public discussion.

Thus, the last amendments were made to the Constitution of the Kyrgyz Republic, by a referendum (popular vote) of December 11, 2016. At the same time, it was ordered that one copy of the Constitution of the Kyrgyz Republic of December 2016 will be kept in the office of the President. So that there was no incident, oversights with the original text of the 2010 constitution.

\section{Conclusion}

Until today, we have been living according to the Constitution's last eighth edition, over the years of sovereignty and independence. In addition, now we are going through the eighth stage of constitutional development in Kyrgyzstan. Let us make a reservation that there is no guarantee that this is the last and final constitutional reform.

We believe that the present appeal to the problem of determining the stages of the constitutional development in Kyrgyzstan as a single process of evolution of the national government and law is an attempt to formulate an urgent scientific problem for both the latest historiography and jurisprudence in Kyrgyzstan, which requires permission from modern scientific principles of objectivity and historicity. Note that there is no other division into stages in the historiography of Kyrgyzstan. We also recognize the fact that our attempt is not final and not the only one; in the future, other points of view or positions of Russian historians may well appear. Social implications in this article are useful in teaching the jurisprudence course in the university and college, as well as in study the constitutional development stages in the Kyrgyz Republic.

\section{Conflicts of Interest}

The authors declare no conflicts of interest regarding the publication of this paper.

\section{References}

Albi, A. (2019). Questionnaire for the Constitutional Law Experts of the Research Project "The Role and Future of National Constitutions in European and Global Governance". In A. Albi, \& S. Bardutzky (Eds.), National Constitutions in European and Global Governance: Democracy, Rights, the Rule of Law (pp. 39-79). T.M.C. Asser Press. https://doi.org/10.1007/978-94-6265-273-6

Alymkozhoev, O. Z. (2015). History of the Kyrgyz of Sayan-Altai and Central Asia in the Studies of Yu. S. Khudyakov. Innovation in Science, 9, 43-48.

Asanbekova, D., Osmonova, A., Abdyldaev, I., Begaliev, E., Ashimov, K., Nurmamat kyzy, K., Narbaev, O., Karimov, S., \& Abdullaeva, Z. (2021). Political System in the Sovereign Kyrgyzstan. Open Journal of Political Science, 11, 266-272. 
https://doi.org/10.4236/ojps.2021.112018

Dononbaeva, A. A. (2016). Constitutional Reforms in the Kyrgyz Republic. Actual Problems of the Humanities and Natural Sciences, 12, 53-56.

Kersting, N., \& Grömping, M. (2021). Direct Democracy Integrity and the 2017 Constitutional Referendum in Turkey: A New Research Instrument. European Political Science. https://doi.org/10.1057/s41304-020-00309-3

Kuldysheva, G., Minbaev, S., Paraidinuulu, S., Mirzaeva, A., Atantaev, A., Rustam, M., Amanbek, K., Abdullaeva, Z., \& Toktobaeva, E. (2021). Kyrgyz Customary Law Development. Open Journal of Social Sciences, 9, 321-327.

https://doi.org/10.4236/jss.2021.91023

Kyrgyz Republic Ministry of Justice (1987). The Constitution of the Kyrgyz Soviet Socialist Republic. http://cbd.minjust.gov.kg/act/view/ru-ru/205064

Kyrgyz Republic Ministry of Justice (2003). Decree of the President of the Kyrgyz Republic on Ensuring Entry into Force of the Kyrgyz Republic Law "On the New Edition of the Kyrgyz Republic Constitution”. http://cbd.minjust.gov.kg/act/view/ru-ru/3963

Kyrgyz Republic Ministry of Justice (2021). Kyrgyz Republic Constitution. http://cbd.minjust.gov.kg/act/view/ru-ru/202913

Lavie, L. (2021). The Constitutionalization of the Civil State: The Self-Definition of Egypt, Tunisia and Yemen Following the Arab Uprisings. Religions, 12, 269.

https://doi.org/10.3390/rel12040269

Saitbekov, A. M. (2016). On the Issue of the Political and Legal Foundations of the Political System in Kazakhstan and Kyrgyzstan. Problems of Modern Science and Education, 3, 243-247.

Sheripov, N. (2014, June 23). Constitutional Development of the Kyrgyz Statehood: The Soviet Stage. Akipress. https://kghistory.akipress.org/unews/un post:2159

Tokpayeva, Z. T. (2013). Historical and Philosophical Genesis of the World Outlook of the Ancient Kyrgyz. Scientific Notes of the Khujand State University Named after Academician B. Gafurov. Humanities, 3, 211-220.

Toktogulov, A. A. (2016). Constitutional Foundations for the Formation of the Jogorku Kenesh of the Kyrgyz Republic. Problems of Modern Science and Education, 9, 64-67.

Young, A. L., Birkinshaw, P., Mitsilegas, V., \& Christou, T. A. (2019). Europe's Gift to the United Kingdom's Unwritten Constitution-Juridification. In A. Albi, \& S. Bardutzky (Eds.), National Constitutions in European and Global Governance: Democracy, Rights, the Rule of Law (pp. 83-139). T.M.C. Asser Press.

https://doi.org/10.1007/978-94-6265-273-6 3 